\title{
Status Nutrisi Kerbau Betina di Peternakan Rakyat Cibungbulang: Pengaruh Suplementasi Indigofera sp dan Gaplek terhadap Perubahan Profil Darah
}

\author{
Nutrient Status of Female Buffalo on Cibungbulang Community Farm: Effect of Indigofera sp and Cassava Flake \\ Supplementation on Blood Profile Changes
}

A Sudarman, N Hidayati, S Suharti

Corresponding email:

a_sudarman@yahoo.com

Departemen Ilmu Nutrisi dan Teknologi Pakan, Fakultas Peternakan, Institut Pertanian Bogor (Bogor Agricultural University/IPB University)

\section{ABSTRACT}

This study aimed to evaluate the effect of Indigofera $\mathrm{sp}$ and cassava flake supplementation on the nutritional status of female buffaloes fed on rice straw and field grasses in smallholder farmers in Cibungbulang, Bogor. This study used four female buffaloes of 4-10 years old and an average body weight of $428.88 \pm 86.05 \mathrm{~kg}$. The treatments were $\mathrm{T} 0=$ without supplementation and $\mathrm{T} 1=$ supplementation of $50 \%$ Indigofera leaf and 50\% cassava flake. The variables observed were body weight gain, blood glucose, cholesterol, total protein, albumin, hematocrit and hemoglobin. Data were analyzed using Paired Samples T-test. The results showed that the nutritional status of buffaloes that were reared in semi-intensive were in normal condition. Supplementation of Indigofera sp and cassava has a positive influence on body weight gain, blood metabolite levels, hematocrit and hemoglobin of female buffaloes. Daily weight gain was obtained at $732.1 \mathrm{~g} \mathrm{head}^{-1} \mathrm{day}^{-1}$. Blood glucose increased from 53.97 to $60.86 \mathrm{mg} \mathrm{dL}^{-1}$, albumin from 3.44 to $3.78 \mathrm{~g} \mathrm{dL}^{-1}$, blood cholesterol from 37.43 to 50.84 $\mathrm{mg} \mathrm{dL}-1$ and hematocrit from 26.75 to $29.75 \%$. The conclusion is that giving supplements of Indigofera and cassava for two weeks can improve the nutritional status of buffaloes reared traditionally.

Key words: blood metabolite, buffalo, cassava flake, hematocrit, haemoglobin, Indigofera $\mathrm{sp}$

\section{ABSTRAK}

Penelitian ini bertujuan untuk mengevaluasi pengaruh suplementasi Indigofera sp dan gaplek terhadap status nutrisi kerbau betina yang diberi pakan berbasis jerami padi dan rumput lapang pada kelompok peternak rakyat di Cibungbulang, Bogor. Penelitian ini menggunakan empat ekor kerbau betina dengan kisaran umur 4 - 10 tahun dan rataan bobot badan 428,88 $\pm 86,05 \mathrm{~kg}$. Perlakuan yang diberikan yaitu T0 = tanpa suplementasi dan $\mathrm{T} 1$ = disuplementasi dengan 50\% Indigofera sp dan 50\% gaplek. Variabel yang diamati adalah pertambahan bobot badan, glukosa darah, kolesterol, protein total, albumin, hematokrit dan hemoglobin. Data dianalisis menggunakan Paired Samples T-test. Hasil penelitian menunjukkan bahwa status nutrisi kerbau yang dipelihara secara semi intensif berada pada kondisi normal. Suplementasi Indigofera sp dan gaplek memberikan pengaruh positif terhadap pertambahan bobot badan, kadar metabolit darah, hematokrit dan hemoglobin dari kerbau betina. Pertambahan bobot badan harian diperoleh sebesar 732,1 g ekor $^{-1}$ hari $^{-1}$. Glukosa darah meningkat dari 53,97 menjadi $60,86 \mathrm{mg} \mathrm{dL}^{-1}$, albumin dari 3,44 menjadi 3,78 $\mathrm{g} \mathrm{dL}^{-1}$, kolesterol darah dari 37,43 menjadi 50,84 $\mathrm{mg} \mathrm{dL}^{-1}$ dan hematokrit dari 26,75 menjadi 29,75\%. Kesimpulannya adalah pemberian suplemen Indigofera dan gaplek selama dua minggu dapat memperbaiki status nutrisi kerbau yang dipelihara secara tradisional.

Kata kunci: gaplek, hematokrit, hemoglobin, Indigofera sp, kerbau, metabolit darah 


\section{PENDAHULUAN}

Kerbau merupakan ternak yang sudah lama dikenal masyarakat Indonesia. Pada umumnya, kerbau hanya digunakan petani untuk membajak sawah. Keadaan ini mulai beralih karena kerbau juga dipelihara untuk menghasilkan daging dengan nilai nutrien daging yang relatif sama dengan daging sapi (Joseph 1996). Budidaya kerbau belum sebaik budidaya sapi, namun usaha ini memberikan kontribusi positif terhadap penyediaan daging dan peningkatan pendapatan petani maupun peternak. Kerbau mempunyai keistimewaan tersendiri dibanding sapi yaitu dapat memanfaatkan serat kasar lebih efisien, daya adaptasi terhadap cekaman lingkungan lebih baik dan pertambahan bobot badan yang relatif cepat dibanding sapi (Yurleni 2013). Agar usaha ini dapat memberikan keuntungan yang optimal bagi pemiliknya maka perlu diperhatikan beberapa hal yang menyangkut manajemen pemeliharaan kerbau, antara lain: bibit, pakan, kandang dan peralatannya, tata laksana pemeliharaan serta kesehatan ternak.

Populasi kerbau di Indonesia sebanyak 2,5 juta ekor (BPS 2016) dengan mayoritas kerbau lumpur. Tetapi, populasinya tidak banyak meningkat karena faktor produksi dan reproduksi yang masih rendah. Populasi kerbau setiap tahun mengalami penurunan. Kecenderungan penurunan populasi kerbau disebabkan oleh sistem manajemen pemeliharaan yang berbasis peternakan tradisional. Selain itu, kerbau merupakan ternak lokal yang masih dipelihara dengan skala kepemilikan rendah dan keterbatasan pengetahuan peternak mengenai manajemen reproduksi yang menyebabkan keterlambatan dewasa kelamin dan rendahnya reproduksi (Toelihere 2006). Pemberian pakan yang masih belum mencukupi kebutuhan kerbau sebagai ternak kerja menyebabkan penurunan populasi yang semakin drastis (Kristianto 2007). Menurut Murti \& Ciptadi (2012) produktivitas kerbau sangat tergantung dari faktor manajemen yang diterapkan, selain dari faktor genetik yang dimiliki oleh ternak itu sendiri. Pada sistem peternakan rakyat, kerbau umumnya hanya diberi pakan berupa rumput dan jerami. Hal demikian tentu saja belum mencukupi kebutuhan nutrisi kerbau. Kekurangan nutrisi tersebut dapat ditanggulangi dengan pemberian pakan dengan kualitas nutrisi baik.

Indonesia sebagai negara tropis memiliki potensi besar untuk menyediakan hijauan pakan bagi ternak. Indigofera sp. memiliki potensi sebagai pakan sumber protein untuk ruminansia karena pertumbuhanya cepat dan memiliki kandungan nutrien yang dapat memenuhi kebutuhan ternak. Indigofera sp. dapat dikembangkan di daerah tropis dengan produksi daunnya mencapai 4.096 kg BK ha ${ }^{-1}$ panen $^{-1}$ dan tanaman ini mempunyai kandungan protein sekitar 27\% (Abdullah \& Suharlina 2010). Jenis pakan lainnya yang potensi adalah singkong.
Potensi singkong di daerah Cibungbulang cukup tinggi. Singkong dapat dimanfaatkan untuk pakan ternak dalam bentuk yang sudah dikeringkan berupa gaplek. Gaplek mempunyai kadar energi yang tinggi akan tetapi rendah kadar protein maupun asam amino. Gaplek juga sebagai sumber karbohidrat yang mudah dicerna. Pemanfaatan gaplek untuk pakan dapat mencapai $75 \%$ dalam konsentrat. Kajian mengenai kerbau di Kabupaten Bogor masih kurang, terutama tentang manajemen pemeliharaan dan kecukupan kebutuhan nutriennya.

Penelitian ini bertujuan untuk mengkaji status nutrisi kerbau yang dipelihara dengan sistem manajemen pemeliharaan tradisional oleh peternak anggota Mitra Tani dan menganalisis pengaruh pemberian pakan tambahan berupa konsentrat yang mengandung Indigofera sp dan gaplek di daerah Cibungbulang, kabupaten Bogor.

\section{METODE}

\section{Ternak dan Pemeliharaan}

Ternak yang digunakan dalam penelitian ini adalah kerbau betina yang masih produktif sebanyak empat ekor dengan kisaran umur 4 - 10 tahun terdapat di Desa Situ Udik, Kecamatan Cibungbulang, Kabupaten Bogor. Kerbau ditempatkan pada kandang semi koloni yang terbuat dari kayu dan bambu. Sistem pemeliharaan disesuaikan dengan manajemen pemeliharaan tradisional peternak di tempat tersebut. Pakan berupa hijauan (rumput lapang dan jerami padi) dan air minum diberikan secara ad libitum. Setiap kerbau diusahakan menerima proporsi jerami dan rumput yang sama.

\section{Komposisi Nutrien Pakan}

Komposisi konsentrat yang digunakan dalam penelitian tersusun dari 50\% Indigofera sp. dan 50\% gaplek. Kandungan nutrien konsentrat disajikan pada Tabel 1.

Tabel 1 Kandungan nutrien konsentrat (50\% Indigofera sp dan $50 \%$ gaplek) dalam BK

\begin{tabular}{lc}
\hline \multicolumn{1}{c}{ Nutrien } & Periode starter \\
\hline Bahan Kering (\%) & 86,66 \\
Protein Kasar (\%) & 13,98 \\
Lemak Kasar (\%) & 1,55 \\
Serat Kasar (\%) & 12,46 \\
TDN (\%) & 76,74 \\
\hline
\end{tabular}

Hasil analisis Laboratorium Pusat Penelitian Sumberdaya Hayati dan Bioteknologi, IPB *Hasil perhitungan TDN menurut Hartadi et al. (1997). TDN (\%) $=-26,865+1,334(\mathrm{SK})+6,598(\mathrm{LK})+1,423(\mathrm{BeTN})$ $+0,967(\mathrm{PK})-0,002(\mathrm{SK}) 2-0,67$ (LK) $2-0,024(\mathrm{SK})(\mathrm{BeTN})-0,055$ (LK) (BeTN) - 0,146 (LK) (PK) + 0,039 (LK)2 (PK). BK: bahan kering, PK: protein kasar, LK: lemak kasar, SK: serat kasar, TDN: total digestible nutrient 


\section{Pelaksanaan Penelitian}

Penelitian dilakukan dengan cara mengamati pola manajemen pemeliharaan yang diterapkan kelompok peternak secara langsung di kandang kerbau selama dua minggu dilanjutkan dengan pemberian pakan tambahan selama dua minggu. Pakan tambahan berupa pellet konsentrat Indigofera sp dan gaplek diberikan sebanyak 1 kg ekor-1hari-1. Bobot badan kerbau diukur dengan menggunakan pita ukur pada awal kunjungan, sebelum dan sesudah perlakuan pemberian konsentrat. Untuk melihat pengaruh pakan terhadap peubah darah, dilakukan pengambilan darah di awal dan akhir penelitian.

\section{Peubah yang Diukur}

\section{Pertambahan Bobot Badan}

Pendugaan bobot badan dilakukan dengan mengukur lingkar dada menggunakan pita ukur dan dihitung berdasarkan rumus perhitungan bobot badan untuk ruminansia besar menurut Schoorl (Sudono et al. 2003) yaitu :

Keterangan:

$$
\mathrm{BB}=\frac{(\mathrm{LD}+22)^{2}}{100}
$$

$$
\begin{aligned}
& \text { BB : bobot badan }(\mathrm{kg}), \\
& \text { LD : lingkar dada }(\mathrm{cm})
\end{aligned}
$$

Pertambahan bobot badan harian dihitung dengan mengurangi bobot badan akhir dengan bobot badan awal kemudian dibagi dengan jumlah hari (14 hari).

\section{Pengambilan Sampel Darah}

Pengambilan sampel darah dilakukan sebelum dan sesudah perlakuan. Pengambilan darah pada vena jugularis dengan menggunakan syringe ukuran $5 \mathrm{~mL}$ dan dimasukkan kedalam tabung ber anti koagulan EDTA, kemudian sampel dibawa ke laboratorium untuk dilakukan analisis hematokrit, hemoglobin dan metabolit darah.

\section{Penghitungan Kadar Hemoglobin (g\%)}

Metode yang digunakan adalah metode Sahli. Tabung sahli diisi larutan $\mathrm{HCl}$ 0,1 N sampai angka 10, lalu sampel darah dihisap dengan pipet sahli dan aspirator sampe batas $0,02 \mathrm{ml}$. Kemudian sampel darah dimasukkan ke dalam tabung sahli dan diletakkan antara kedua bagian standar warna dalam alat hemoglobinometer, warna akan berubah menjadi coklat akibat reaksi $\mathrm{HCl}$ dengan hemoglobin dan membentuk asam hematin. Setelah itu, larutan tersebut ditetesi dengan aquades sedikit demi sedikit sambil diaduk hingga warna larutan sama dengan warna standar hemoglobinometer. Nilai hemoglobin diketahui dengan membaca tinggi permukaan pada tabung sahli, skala jalur g\% menunjukkan jumlah hemoglobin dalam gram per $100 \mathrm{ml}$ darah (Sastradipraja dan Hartini. 1989).

\section{Perhitungan Nilai Hematokrit (\%)}

Nilai hematokrit ditentukan dengan metode mikrohematokrit. Pipa mikrokapiler dihisap dengan memiringkan tabung yang berisi sampel darah dengan menempatkan ujung mikrokapiler yang bertanda merah. Pipa diisi sampai $4 / 5$ bagian kemudian ujung pipa disumbat dengan crestaseal lalu ditempatkan di microcentrifuge dengan kecepatan $12000 \mathrm{rpm}$ selama 5 menit. Penentuan nilai hematokrit dilakukan dengan mengukur \% volume eritrosit (lapisan merah) dari darah menggunakan alat baca microcapillary hematocrite reader (Sastradipraja dan Hartini, 1989)

\section{Analisis Metabolit Darah}

Analisis metabolit yang dilakukan antara lain yaitu kadar glukosa darah, protein total, albumin darah, dan kolesterol darah. Analisa tersebut dilakukan dengan metode GPO-PAP menggunakan KIT sesuai peubah yang diamati. Analisis metabolit menggunakan alat sentrifuge untuk pengambilan plasma darah, dan menggunakan spektrofotometer untuk mengetahui absorbansi masingmasing peubah dengan panjang gelombang tertentu.

$\begin{array}{ll}\text { Konsentrasi Glukosa }\left(\mathrm{mg} \mathrm{dL}^{-1}\right) & =\frac{\Delta \mathrm{A} \text { Sampel }}{\Delta \mathrm{A} \text { Standar }} \times 100 \\ \text { Konsentrasi Kolesterol }\left(\mathrm{mg} \mathrm{dL}^{-1}\right) & =\frac{\Delta \text { S Sampel }}{\Delta \mathrm{ASta}} \times 200\end{array}$

Konsentrasi Kolesterol $\left(\mathrm{mg} \mathrm{dL}^{-1}\right)=\frac{\Delta \text { A Sampel }}{\Delta \text { A Standar }} \times 200$

Konsentrasi Protein total $\left(\mathrm{mg} \mathrm{dL}^{-1}\right) \quad=\frac{\Delta \mathrm{A} \text { Sampel }}{\Delta \mathrm{A} \text { Standar }} \mathrm{x} 8$

Konsentrasi Albumin $\left(\mathrm{mg} \mathrm{dL}^{-1}\right)=\frac{\Delta \text { A Sampel }}{\Delta \text { A Standar }} \mathrm{X} 4$

\section{Analisis Data}

Data pertambahan bobot badan sebagai data pendukung dianalisis secara deskriptif. Sedangkan data metabolit, hematokrit dan hemoglobin darah dianalisis dengan menggunakan Paired Samples T-test (Sudjana 1997) dengan bantuan program SPSS 22.

\section{HASIL DAN PEMBAHASAN}

\section{Gambaran Umum Lokasi dan Kelompok Peternak}

Desa Situ Udik terletak pada ketinggian sekitar 250 sampai 300 meter diatas permukaan laut dengan jenis tanah latosol dengan $\mathrm{pH}$ berkisar 5 sampai 7 . Berdasarkan monografi Desa Situ Udik Tahun 2010, luas wilayah desa Situ Udik adalah $363 \mathrm{Ha}$, yang terdiri dari pertanian $205 \mathrm{Ha}$, peternakan $85 \mathrm{Ha}$, perikanan $9 \mathrm{Ha}$, perkebunan $44 \mathrm{Ha}$, kehutanan $14 \mathrm{Ha}$ dan lain-lain $6 \mathrm{Ha}$. Lahan pertaniannya merupakan lahan basah, dengan sistem pengairan semi teknis dan pengairan sistem sederhana.

Mitra Tani adalah sebuah kelompok tani didirikan pada tahun 1988 di desa Situ Udik, Kecamatan Cibungbulang, Kabupaten Bogor. Sebanyak 10 ekor kerbau yang berasal dari bantuan pemerintah dipelihara bersama oleh anggota kelompok. Ternak kerbau tersebut tidak dipekerjakan dan sepanjang hari berada di 
dalam kandang semi koloni yang dibersihkan setiap pagi hari. Kerbau tersebut tidak pernah dimandikan dan 2-3 bulan sekali dilakukan pemeriksaan kesehatan oleh mantri kesehatan hewan. Pakan terdiri atas rumput dan jerami padi diberikan pada pagi dan sore hari ad libitum.

\section{Konsumsi Pakan dan Pertambahan Bobot Badan Kerbau}

Konsumsi konsentrat dan pertambahan bobot badan kerbau selama penelitian diperlihatkan pada Tabel 2 . Manajemen pemberian pakan yang biasa dilakukan oleh peternak secara tradisional untuk ternak kerbau yang dipelihara mereka nampaknya belum memadai. Pemberian pakan hanya rumput dan jerami, meskipun diberikan ad libitum belum dapat mencukupi kebutuhan nutren untuk menaikkan bobot badan selama dua minggu pemberian pakan dengan tidak adanya pertambahan bobot badan (Tabel 2). Kurangnya konsumsi nutrien selain berpengaruh terhadap produksi (pertambahan bobot badan yang rendah) dikhawatirkan juga dapat mengganggu tampilan reproduksi kerbau, seperti tertundanya estrus pertama dan rendahnya calving interval.

Penambahan suplementasi konsentrat berupa 50\% Indigofera $\mathrm{sp}+50 \%$ gaplek dengan kandungan Protein kasar 13,98\% dan TDN 76,74\% yang diberikan selama dua minggu menunjukkan perbaikan status nutrien kerbau yang diindikasikan oleh adanya pertambahan bobot badan. Pertambahan bobot badan sebesar 0,73 kg ekor-1hari-1 dapat dicapai dengan konsumsi suplemen konsentrat sebanyak 813,8 kg ekor-1 hari-1. Pada Tabel 2 terlihat sebelum pemberian suplemen konsentrat bobot badan kerbau adalah 488,75 kg dan dua minggu setelah pemberian suplemen konsentrat bobot badan akhirnya menjadi 499,75 kg. Rendahnya pengetahuan peternak akan pemberian pakan yang benar yang memberi pakan ternaknya hanya berdasarkan pengetahuan yang diwariskan secara turun menurun perlu mendapat perhatian dan perbaikan dari pemangku kepentingan yang lain.

Tabel 2 Bobot badan, konsumsi konsentrat, dan pertambahan bobot badan harian kerbau betina selama percobaan

\begin{tabular}{|c|c|}
\hline Peubah & Rataan \pm SD \\
\hline \multicolumn{2}{|l|}{ Bobot badan } \\
\hline Awal pakan peternak, kg ekor ${ }^{-1}$ & $488,75 \pm 74,35$ \\
\hline Akhir pakan peternak, kg ekor-1 & $488,75 \pm 74.35$ \\
\hline $\begin{array}{l}\text { Pertambahan bobot badan harian (PBBH), } \\
\text { g ekor }^{-1} \text { hari }^{-1}\end{array}$ & 0 \\
\hline Konsumsi konsentrat , g ekor ${ }^{-1}$ hari $^{-1}$ & $813,84 \pm 329,14$ \\
\hline \multicolumn{2}{|l|}{ Bobot Badan } \\
\hline Awal pemberian konsentrat, kg ekor ${ }^{-1}$ & $488,75 \pm 74,35$ \\
\hline Akhir pemberian konsentrat, kg ekor-1 & $499,75 \pm 79,81$ \\
\hline $\begin{array}{l}\text { Pertambahan bobot badan harian (PBBH), } \\
\text { g ekor-1 }^{-1} \text { hari-1 }^{-1}\end{array}$ & $732,1 \pm 417,01$ \\
\hline
\end{tabular}

\section{Pengaruh Perlakuan terhadap Metabolit Darah, Hematokrit dan Hemoglobin Kerbau di Peternakan Kelompok}

Kadar metabolit darah, hematokrit dan hemoglobin kerbau yang dipelihara di peternakan kelompok sebelum dan sesudah diberi perlakuan disajikan pada Tabel 3 . Metabolit darah sangat dipengaruhi oleh jumlah nutrien yang dikonsumsi, faktor lain yang mempengaruhi metabolit darah adalah umur, stress dan kesehatan ataupun faktor eksternal berupa perubahan suhu lingkungan, infeksi kuman penyakit, dan lain sebagainya (Guyton \& Hall 1997). Gambaran profil metabolit darah kerbau digunakan untuk membantu mengidentifikasi masalah kecukupan nutrisi serta sistem manajemen pemeliharaan. Hubungan antara status nutrisi dengan produktivitas dan repoduksi sangat erat kaitanya (Wetterman et al. 2003). Kandungan nutrien merupakan faktor utama yang menghambat sistem produksi ternak di daerah tropis. Kekurangan nutrien atau konsumsi nutrien yang tidak cukup dapat berpengaruh langsung terhadap efisiensi reproduksi (Salem et al. 2006), seperti rendahnya kinerja reproduksi dan produktivitas.

Perlakuan pemberian konsentrat (Indigofera sp. dan gaplek) sangat nyata $(\mathrm{P}=0,007)$ meningkatkan kadar glukosa darah. Kadar glukosa darah sebelum perlakuan sebesar 53,97 $\pm 8,07 \mathrm{mg} \mathrm{dL}^{-1}$ dan setelah perlakuan sebesar 60,86 \pm 9,01 mg dL-1. Kadar ini masih dalam kisaran normal untuk kadar glukosa darah kerbau yang menurut Zakaria et al. (2003) kadar glukosa normal kerbau berkisar 40 - $70 \mathrm{mg} \mathrm{dL}-1$. Meningkatnya kadar glukosa darah setelah pemberian suplemen konsentrat menunjukkan bahwa kerbau memperoleh cukup konsumsi sumber glukosa dibandingkan dengan hanya pemberian rumput dan jerami saja.

Glukosa adalah salah satu substrat metabolisme utama yang diperlukan untuk fungsi produksi dan reproduksi pada ruminansia. Rendahnya kadar glukosa darah sebagaimana dialami kerbau ketika tidak diberi konsentrat dapat menyebabkan tingginya konsentrasi

Tabel 3 Kadar metabolit darah, hematokrit dan hemoglobin kerbau sebelum dan sesudah pemberian kosentrat (rataan \pm simpangan baku)

\begin{tabular}{lllc}
\hline Peubah & Sebelum & Sesudah & Signifikansi \\
\hline $\begin{array}{l}\text { Metabolit darah } \\
\text { Glukosa darah, } \\
\mathrm{mg} \mathrm{dL}^{-1}\end{array}$ & $53,97 \pm 8,07$ & $60,86 \pm 9,01$ & 0,007 \\
$\begin{array}{l}\text { Protein total, } \\
\text { g dL }^{-1}\end{array}$ & $7,46 \pm 0,55$ & $7,46 \pm 0,67$ & 1,000 \\
$\begin{array}{l}\text { Albumin, g dL } \\
\text { Kolesterol, }\end{array}$ & $3,44 \pm 0,25$ & $3,78 \pm 0,22$ & 0,007 \\
mg dL $^{-1}$ & $37,43 \pm 8,23$ & $50,84 \pm 9,01$ & 0,088 \\
$\begin{array}{l}\text { Hematokrit, \% } \\
\text { Hemoglobin, }\end{array}$ & $26,75 \pm 2,99$ & $29,75 \pm 3,59$ & 0,081 \\
g 100 ml & $9,78 \pm 0,46$ & $9,85 \pm 0,85$ & 0,824 \\
\hline
\end{tabular}

http://journal.ipb.ac.id/index.php/jurnalintp 
Non Esterified Fatty Acids (NEFA) yang mempunyai efek toksik terhadap folikel, oosit, embrio, dan fetus (Arthur et al. 2001), dan menurunnya sekresi GnRH oleh hipotalamus (Murray et al. 2003). Penurunan GnRH menghambat sintesis FSH. Akibatnya performa reproduksi kerbau terganggu.

Perlakuan pemberian konsentrat (Indigofera sp. dan gaplek) tidak berpengaruh terhadap kadar protein total darah. Kadar protein total sebelum dan sesudah perlakuan sebesar 7,46 $\mathrm{g} \mathrm{dL}^{-1}$. Hal ini menunjukkan tidak terjadi kenaikan atau penurunan kadar protein total pada kerbau namun masih berada dalam kisaran normal. Kadar total protein dalam plasma darah kerbau normal yaitu 5,63 - 8,10 $\mathrm{g} \mathrm{dL}^{-1}$ (Khan et al. 2009). Peningkatan atau penurunan konsentrasi protein total dipengaruhi oleh konsentrasi albumin atau globulin atau keduanya dalam sirkulasi darah (Lassen 2005).

Hati mensintesis dan melepaskan lebih dari 90\% protein plasma (Martini et al. 1992). Menurut Kaneko et al. (1997) terdapat tiga fraksi utama protein dalam darah, yaitu albumin, globulin dan fibrinogen. Albumin, fibrinogen, dan globulin (50-80\% globulin) disintesis di organ hati, sedangkan sisa globulin lainnya dibentuk di jaringan limfoid. Secara fisiologis, konsentrasi protein serum dipengaruhi oleh umur, pertumbuhan, hormonal, jenis kelamin, kebuntingan, laktasi, nutrisi, stres dan kehilangan cairan (Kaneko et al. 1997).

Perlakuan pemberian konsentrat (Indigofera sp. dan gaplek) sangat nyata $(\mathrm{P}=0,007)$ meningkatkan kadar albumin darah. Rataan kadar albumin kerbau penelitian sebelum perlakuan sebesar 3,44 $\pm 0,25 \mathrm{~g} \mathrm{dL}^{-1}$ dan mengalami kenaikan setelah perlakuan menjadi 3,78 \pm $0,22 \mathrm{~g} \mathrm{dL}^{-1}$. Hasil penelitian menunjukkan pemberian konsentrat Indigofera sp dan gaplek menghasilkan kadar albumin yang normal dan kecukupan nutrien khususnya protein. Albumin merupakan protein utama yang ada di dalam plasma darah yang diproduksi oleh hati dan menyusun sekitar $40 \%$ dari total protein darah (Kearl 1982). Sebagai protein utama dalam darah albumin berperan dalam banyak fungsi seperti mempertahankan tekanan pembuluh darah dan mengangkut berbagai zat di dalam darah. Salah satu penyebab rendahnya kadar albumin darah adalah kurangnya konsumsi nutrien (Throop et al. 2004). Kekurangan konsumsi nutrien akan mengakibatkan rendahnya performa produksi dan reproduksi ternak.

Pemberian konsentrat Indigofera sp. dan gaplek meningkatkan kadar kolesterol darah $(\mathrm{P}=0,08)$. Rataan kadar kolesterol darah kerbau sebelum perlakuan yaitu sebesar 37,43 $\pm 8,23 \mathrm{mg} \mathrm{dL}^{-1}$ dan meningkat setelah perlakuan menjadi 50,84 $\pm 9,01 \mathrm{mg} \mathrm{dL}^{-1}$ (Tabel 3). Terjadinya peningkatan kadar kolesterol setelah pemberian Indigofera sp. dan gaplek sesuai dengan pendapat Guyton \& Hall (1997) bahwa kualitas dan kuantitas pakan yang baik menentukan nilai kolesterol darah. Pakan dengan kualitas nutrien yang mencukupi kebutuhan ternak dapat meningkatkan kadar kolesterol darah.

Kolesterol dalam darah sangat menentukan performa reproduksi ternak. Pemberian pakan berupa rumput dan jerami padi oleh peternak kelompok tidak mampu meningkatkan kadar kolesterol darah untuk memenuhi kebutuhan bereproduksi dengan baik. Kerbau yang dipelihhara oleh peternak cenderung memiliki umur beranak pertama mencapai 4 - 5 tahun. Padahal, umur beranak kerbau normal berkisar $2-2,5$ tahun (Toelihere 2006).

Kolesterol merupakan prekursor pembentuk hormon steroid. Sintesis dan ketersediaannya dalam sirkulasi darah menentukan jumlah hormon steroid yang disekresikan (Yadav et al. 1995). Menurut Hardjopranjoto (1995), rendahnya kadar kolesterol dalam darah dapat menekan birahi dan ovulasi atau mengurangi jumlah sel telur yang diovulasikan. Rendahnya kolesterol darah pada ternak betina dapat diikuti oleh berahi tenang (silent heat) atau berahi pendek (subestrus), dan memperpanjang masa anestrus).

Kadar hematokrit kerbau cenderung mengalami peningkatan $(\mathrm{P}=0,08)$ dengan pemberian pakan yang mengandung Indigofera dan gaplek. Rataan kadar hematokrit kerbau penelitian sebelum perlakuan sebesar 26,75 \pm 2,99 dan mengalami kenaikan setelah perlakuan menjadi 29,75 $\pm 3,59$ (Tabel 3). Peningkatan nilai hematokrit dipengaruhi oleh kandungan protein pakan, kandungan protein pakan tambahan yang mengandung indigofera dan gaplek lebih baik dibandingkan pakan hijauan berupa rumput dan jerami saja yang biasa diberikan oleh peternak. Protein merupakan substansi penting pembentuk eritrosit (Soeharsono \& Hermawan 2010) dan juga sel darah lain yang merupakan komponen hematokrit (volume sel yang dimampatkan).

Penambahan konsentrat Indigofera sp. dan gaplek memberikan hasil yang tidak nyata $(P=0,8)$ terhadap kadar hemoglobin. Rataan kadar hemoglobin kerbau penelitian sebelum perlakuan sebesar 9,78 \pm 0,46 g 100 $\mathrm{mL}^{-1}$ dan mengalami sedikit peningkatan setelah perlakuan menjadi 9,85 \pm 0,85 g $100 \mathrm{~mL}^{-1}$ (Tabel 3). Kenaikan kadar hemoglobin berkorelasi positif dengan peningkatan kadar hematokrit.

Pada hewan normal jumlah hemoglobin sebanding dengan kadar eritrosit dan hematokrit (Sonjaya 2012). Guyton \& Hall (1997) menambahkan bahwa bila volume sel darah merah menurun maka pembentukan hemoglobin pada sumsum tulang belakang juga menurun. Metabolit darah sangat dipengaruhi oleh jumlah zat makanan yang di konsumsi oleh ternak, faktor lain yang mempengaruhi metabolit darah adalah umur, stress dan kesehatan ataupun faktor eksternal 
berupa perubahan suhu lingkungan dan infeksi kuman penyakit (Guyton \& Hall 1997). Gambaran profil metabolit darah kerbau digunakan untuk membantu mengidentifikasi masalah kecukupan nutrisi serta sistem manajemen pemeliharaan. Hubungan antara status nutrisi dengan produktivitas dan repoduksi sangat erat kaitanya (Wetterman et al. 2003). Kandungan nutrisi merupakan faktor utama yang menghambat sistem produksi ternak di daerah tropis. Kekurangan nutrisi atau masukan nutrisi yang tidak cukup dapat berpengaruh langsung terhadap efisiensi reproduksi (Salem et al. 2006).

\section{SIMPULAN}

Sistem pemberian pakan tradisional yang diterapkan peternak untuk kerbaunya berupa hanya jerami padi dan rumput, meskipun diberikan ad libitum, tidak dapat meningkatkan bobot badan ternak. Pemberian suplemen konsentrat Indigofera dan gaplek selama dua minggu dapat memperbaiki status nutrisi kerbau penelitian. Pemberian pakan tambahan berupa pellet daun Indigofera sp dan gaplek dapat meningkatkan bobot badan kerbau serta memperbaiki kadar metabolit dan profil darah. Namun protein total dan hemoglobin tidak terpengaruh dengan pemberian pakan tambahan.

\section{DAFTAR PUSTAKA}

Abdullah, L \& Suharlina. 2010. Herbage yield and quality of two vegetative parts of Indigofera at different time of first regrowth defoliation. Media Peternakan. 33:44-49

Arthur, GH, David EN \& Pearson H. 2001. Veterinary Reproduction and Obstetrics. 8th ed. Bailliere Tindall, London.

BPS] Badan Pusat Statistik. 2016. Statistik Indonesia 2016. Jakarta (ID): Badan Pusat Statistik [diunduh 23 Maret 2017]. Tersedia pada: http://www.bps.go.id/.

Guyton MD \& Hall JE. 1997. Fisiologi Kedokteran. Setiawan I, editor. Jakarta (ID): Penerbit Buku Kedokteran EGC.

Hardjopranjoto H.S. 1995. Ilmu Kemajiran pada Ternak. Surabaya (ID): Airlangga University Press.

Hartadi HS, Reksohadiprodjo \&Tillman AD. 1997. Tabel Komposisi Pakan untuk Indonesia. Yogyakarta (ID). Gadjah Mada University Press.

Joseph G. 1996. Status asam basa dan metabolisme mineral pada ternak kerbau lumpur yang diberi pakan jerami padi dan konsentrat dengan penambahan natrium [tesis]. Bogor (ID): Institut Pertanian Bogor.

Kaneko JJ. 1997. Serum proteins and dysproteinemia. Di dalam Kaneko J.J., J.W. Harvey, M.L. Bruss, Editor. Clinical Biochemistry of Domestic Animals. Edisi 5. Academic Press. London. Pp. 117 -138.

Kearl LC. 1982. Nutrition Requirements of Ruminants in Developing Countries. International Feedstuff Utah Agriculture Experiment Station. 1st editor. Logan (US): Utah State University.

Khan HM, Bhakat M, Mohanty TK, Gupta AK, Raina VS \& Mir MS. 2009. Peripartum reproductive disorders in buffaloes-An overview. Online Veterinary Journal. 4 (2): 38

Kristianto L. K. 2007. Pengembangan perbibitan kerbau kalang dalam menunjang agrobisnis dan agrowisata di Kalimantan Timur. Pros. Semiloka Kerbau. Jambi (ID): Pusat penelitian dan Pengembangan Peternakan Bogor
Lassen ED. 2005. Laboratory evaluation of plasma and serum protein. Di dalam Thrall MA, editor. Veterinary Hematology and Clinical Chemistry. Lippincott Williams \& Wilkins. Maryland.

Martini FH, Ober WC, Garrison C \& Weleh K. 1992. Fundamentals of Anatomy and Physiology. Edisi 2. New Jersey (US): Prentice Hall, Englewood Cliffs.

Murray RK, Granner DK, Mayes PA, \& Rodwell VW.2003. Biokimia Harper. Edisi ke-25. Jakarta (ID): EGC.

Murti TW \& Ciptadi G. 2012. Kerbau Perah dan Kerbau Kerja. Jakarta (ID): Mediyatama Sarana Perkasa.

Salem MB, Djemali M, Kayouli C \& Majdoub A. 2006. A review of enviromental and management factors affecting the productive performance of Holstein Friesian dairy herds in Tunisia. Livestock Research for Rural Development. 18(4): 123-129.

Sastradipradja D \& Hartini S. 1989. Fisiologi Veteriner. Bogor (ID): IPB Press.

Soeharsono \& Hermawan. E 2010. Fisiologi Ternak: Fenomena dan Nomena Dasar, Fungsi, dan Interaksi Organ pada Hewan. Bandung (ID) : Widya Padjajaran, Bandung.

Sonjaya H. 2012. Dasar Fisiologi Ternak. Bogor (ID): Institut Pertanian Bogor

Sudjana MA. 1997. Metode Statistik Edisi ke-5. Bandung : Tarsito.

Sudono A \& Rusdiana RF, Setiawan BS. 2003. Beternak Sapi Perah secara Intensif. Jakarta (ID): Agromedia Pustaka.

Throop J L, Kerl ME \& Cohn LA. 2004. Albumin in health and disease: causes and treatment of hypoalbuminemia. Compendium. 26: 940948.

Toelihere MR. 2006. Ilmu Kebidanan pada Ternak Sapi dan Kerbau. Jakarta (ID): UI Press.

Wetterman RP, Hill GM \& Boyd ME. 2003. Reproductive performance of postpartum beef cows after short-term calf separation and dietary energy and protein supplementation. Theriogenology. 4: 433-443.

Yadav NK, Lohan JS, Singh B \& Chan D. 1995. Studies on some serum constituents in anestrus buffaloes. Indian Journal Animal Research. 29: 85-88.

Yurleni. 2013. Produktivitas dan karakteristik daging kerbau dengan pemberian pakan yang mengandung asam lemak terproteksi [disertasi]. Bogor (ID): Institut Pertanian Bogor.

Zakaria K, Arifin M \& Mawati S. 2003. Parameter darah kerbau yang mendapat pakan basal jerami padi dan tambahan urea molases. Prosiding Seminar Nasional Teknologi Peternakan dan Veteriner. Bogor (ID): Pusat Penelitian dan Pengembangan Peternakan Bogor 